\title{
Nutrient Consumption by Chenin Blanc grown in Sand Culture and Seasonal Changes in the Chemical Composition of Leaf Blades and Petioles
}

\author{
W. J. CONRADIE \\ Oenological and Viticultural Research Institute, Private Bag X5026, Stellenbosch.
}

\begin{abstract}
The seasonal utilization of $\mathrm{N}, \mathrm{P}, \mathrm{K}, \mathrm{Ca}$ and $\mathrm{Mg}$ by the various aerial and underground organs of bearing Chenin blanc/99R grown in sand culture under South African climatic conditions was tabulated. During the production of one ton of grapes, the bunches accumulated 1,$39 ; 0,25 ; 1,98 ; 0,17$ and $0,09 \mathrm{~kg} N, P, K$, $\mathrm{Ca}$ and $\mathrm{Mg}$ respectively, the permanent parts of the vine accumulated a further 0,$73 ; 0,10 ; 0,19 ; 0,14$ and $0,08 \mathrm{~kg}$, and the vegetative growth (leaves plus prunings) accumulated 1,$77 ; 0,37 ; 0,88 ; 1,70$ and $0,43 \mathrm{~kg}$.

Appreciable seasonal changes were found in the chemical composition of both leaf blades and petioles. The petioles showed a reasonably stable composition during the month following bloom verifying the results of other workers, and samples for analyses should, therefore, be collected at this stage. However, the nutrient concentrations in the leaf blades remained unstable.

The nutrient export figures obtained in this experiment may be used in conjunction with occasional petiole analyses as a basis for fertilizer recommendations. However, in the case of petiole analyses reliable norms are still lacking.
\end{abstract}

In order to carry out realistic fertilization programmes in vineyards, it is essential to know what quantities of nutrients are removed by the vines. Nutrient removal figures have been calculated since the nineteenth century (Conradie, 1980), but none of these values could be regarded as representative for South African conditions. It was particularly clear that the contribution of the roots to the nutritional pattern of the vine should be thoroughly investigated under local conditions where appreciable reserves could accumulate during the post harvest period.

The soil bank theory (the quantity of nutrients removed by the crop should be replaced annually) is still accepted to a large extent, especially in Europe, and fertilizer recommendations are based upon it (Cook, 1966). However, soil analyses, which is an integral part of this concept, is not always reliable in determining the nutritional status of a vine, mainly because of the variety of soil types, diseases and climatic differences. Tissue analyses are regarded by some as being more reliable than soil analyses, and an impressive amount of research has been carried out in order to establish reliable norms and to find the most sensitive tissue or organ capable of reflecting the nutritional status of the vine (Beyers, 1962; Christensen, 1969; Alexander \& Woodham, 1970; Lévy, Chaler, Camhaji \& Hégo, 1972; Cummings, 1977). Reliable interpretation of analytical figures is rendered difficult by seasonal fluctuations in nutrient contents of leaves. In South Africa Beyers, Pienaar \& Terblanche (1968) constructed calibration curves by means of which analytical data obtained on leaves at any stage between December and March may be "corrected" to such values as can be expected at the standard reference date of 31st January. However, this research was done for two table grape varieties, Waltham Cross (Datier de Beirut) and Barlinka, which are grown in South Africa under soil and climatic conditions which differ vastly from those of wine grapes. Furthermore, their norms were for leaf blade analyses only, whereas it is widely accepted to-day that petiole analyses give a better indication of the nutritional status of vines, especially for $N$ and $K$ (Cook, 1966; Winkler, et al., 1974; Cummings, 1977).

In order to establish the seasonal consumption figures for various nutrients of grapevines under the climatic conditions similar to those of the traditional wine areas of the Western Cape, an experiment was carried out in sand culture using the most commonly planted scion/rootstock combination (i.e. Chenin blanc/99R) as test plants. The aim was further to identify the best time for leaf sampling as well as to determine the part of the leaf tissue most likely to give reliable results.

\section{MATERIALS AND METHODS}

Chenin blanc vines grafted on $99 \mathrm{R}$ and grown in sand culture were used as test plants. Whole vines were taken 14 times in the course of their third growing season and were separated into the various organs and analysed. Eight vines were used for each set of determinations. Details of the experimental layout, care, sampling and analyses of the vines have been described previously (Conradie, 1980 \& 1981).

\section{RESULTS AND DISCUSSION}

Amounts of nutrients removed by the crop: The vines yielded an average of $2,6 \mathrm{~kg}$ grapes per vine, which corresponds to a yield of about six tons per hectare. Table 1 shows the amounts of $N, P, K, C a$ and $M g$ accumulated by the various organs, calculated for a production of one ton of grapes. (Permanent parts of the vine include all organs remaining on the vine after pruning).

S. Afr. J. Enol. Vitic., Vol. 2. No. 1. 1981 
TABLE 1

Amounts of $N, P, K, C a$ and $M g$ associated with the various organs of Chenin blanc/99R during the production of one ton of grapes

\begin{tabular}{|c|c|c|c|c|c|c|c|c|c|}
\hline Element & $\begin{array}{r}\mathrm{R} \\
(\mathrm{kg})\end{array}$ & $\begin{array}{l}\text { by } \\
(\%)\end{array}$ & $\underset{\substack{\text { pern } \\
(\mathrm{kg})}}{\mathrm{N}}$ & $\begin{array}{l}\text { y } \\
\text { arts } \\
(\%)\end{array}$ & $\begin{array}{r}\text { Lo } \\
(\mathrm{kg})\end{array}$ & $\begin{array}{l}\text { gh } \\
(\%)\end{array}$ & $\begin{array}{r}\mathrm{R} \\
(\mathrm{kg})\end{array}$ & $\begin{array}{l}\text { by } \\
(\%)\end{array}$ & $\begin{array}{c}\text { Total } \\
(\mathrm{kg})\end{array}$ \\
\hline 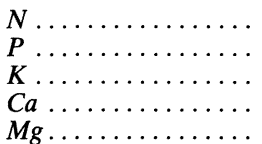 & $\begin{array}{l}1,39 \\
0,25 \\
1,98 \\
0,17 \\
0,09\end{array}$ & $\begin{array}{r}35,8 \\
34,2 \\
64,8 \\
8,4 \\
14,9\end{array}$ & $\begin{array}{l}0,73 \\
0,10 \\
0,19 \\
0,14 \\
0,08\end{array}$ & $\begin{array}{r}18,7 \\
14,1 \\
6,2 \\
6,9 \\
12,5\end{array}$ & $\begin{array}{l}1,21 \\
0,29 \\
0,47 \\
1,40 \\
0,32\end{array}$ & $\begin{array}{l}31,1 \\
39,8 \\
15,4 \\
69,8 \\
53,9\end{array}$ & $\begin{array}{l}0,56 \\
0,08 \\
0,41 \\
0,30 \\
0,11\end{array}$ & $\begin{array}{l}14,4 \\
11,9 \\
13,6 \\
14,9 \\
18,7\end{array}$ & $\begin{array}{l}3,89 \\
0,72 \\
3,05 \\
2,01 \\
0,60\end{array}$ \\
\hline
\end{tabular}

The ratio of total quantities of $N, P, K, C a$ and $M g$ absorbed during the season amounted to 5,39: $1: 4,23: 2,79: 0,84$. The fraction of the absorbed nutrients removed by the crop differed drastically from element to element. It was highest for $K(64,8 \%)$, smaller for $N$ and $P(35,8 \%$ and $34,2 \%$, respectively) and relatively unimportant for $C a$ and $M g(8,4 \%$ and 14,9\%). The actual amounts of $N, P$ and $K$ removed by the production of 1 ton of grapes per hectare $(1,39 \mathrm{~kg}, 0,25$ $\mathrm{kg}$ and 1,98 kg), correspond well with results obtained in France. In the Charente Lafon et al. (1965), reported figures amounting to $1,43 \mathrm{~kg}, 0,22 \mathrm{~kg}$ and $1,59 \mathrm{~kg}$ for $N$, $P$ and $K$ respectively, and more recently in Colmar, Marocke, et al. (1976), estimated the consumption of $N$, $P$ and $K$ at 1,$70 ; 0,26$ and $2,32 \mathrm{~kg} /$ ton.

The amount of $\mathrm{Ca}$ removed by the crop in this experiment $(0,17 \mathrm{~kg} /$ ton $)$ is much lower than the corresponding figure (estimated at $0,40 \mathrm{~kg} /$ ton) obtained by Lafon et al. (1965) for vineyards in production. The difference may possibly be ascribed to the generally calcareous nature of the vineyard soils on which the study by Lafon et al. (1965) was conducted.

The amount of $M g$ removed $(0,09 \mathrm{~kg} / \mathrm{ton})$ is higher than the figure of $0,05 \mathrm{~kg} /$ ton reported by Lafon et al. (1965). This difference may also be ascribed to the soil, as $M g$ deficiencies have been widely reported in European vineyard soils (Delas, 1968; Eggenberger et al., 1975).

The quantities of $N, P, K, C a$ and $M g$ contained in the vegetative growth (leaves and prunings) amounted to 1,$77 ; 0,37 ; 0,88 ; 1,70$ and $0,43 \mathrm{~kg} /$ ton of grapes. The figures for $N, P$ and $K$ compare reasonably well with those reported by Lafon et al. (1965) for the western district of Charente in France $(2,1 ; 0,27$ and 1,21 kg/ton), but are much lower than the quantities found in Colmar by Marocke et al. (1976) $(3,70 ; 0,48 ;$ and 3,49 kg/ton, respectively). The amount of $\mathrm{Ca}$ contained in the vegetative growth is lower than the $3,02 \mathrm{~kg} /$ ton found by Lafon et al. (1965), whereas the corresponding amount of $M g$ is considerably higher $(0,24 \mathrm{~kg} / \mathrm{ton})$, again probably due to the calcareous nature of the soil on which the experiment in France was conducted.

Table 1 further illustrates the annual accumulation of nutrients by the permanent parts of the vine. Appreciable amounts of $N, P$ and $M g(18,7 \% ; 14,1 \%$ and $12,5 \%$ of the seasonal consumption) are stored in this manner. Therefore, if all the leaves and prunings are returned to the soil, a crop of one ton of grapes per hectare may be expected to remove from the soil: $2,12 \mathrm{~kg} N ; 0,35 \mathrm{~kg} P$; $2,17 \mathrm{~kg} K ; 0,31 \mathrm{~kg} C a$ and $0,17 \mathrm{~kg} M g$ respectively. The vines lost the major share of the seasonal $\mathrm{Ca}$ uptake $(84,7 \%)$ through leaf fall and pruning. However, even when taking this into account, the amount of $\mathrm{Ca}$ permanently removed from the soil by the production of one ton of grapes $(0,31 \mathrm{~kg})$ is still comparable to the $P$ removal $(0,35 \mathrm{~kg})$. On the highly leached soils of the Western Cape $C a$ nutrition should, therefore, receive more attention.

Seasonal changes in nutritional status of leaves: The seasonal changes in $\mathrm{N}, \mathrm{P}, \mathrm{K}, \mathrm{Ca}$ and $\mathrm{Mg}$ contents of leaf blades and petioles are shown in Fig. 1 .

$N$ uptake has been discussed previously (Conradie, 1980 ), and as indicated in Fig. 1 , the $N$ concentration in the blades decreased during bloom as well as during the month following bloom, after which there was a slight increase during the period preceding véraison, followed by a decrease during the ripening period. The petioles showed a substantial decrease in $N$ during bloom, followed by a relatively stable period lasting up to harvest. In the case of $P$ the pattern for the blades was comparable to that of $N$, but the pattern for the petioles showed larger variations, the only relatively stable period being the month following bloom. However, in contrast to the results of Cummings (1977), the $P$ concentration in the petioles was still more stable than that in the blades. The results of this study for $P$ levels in petioles correspond fairly well with the results obtained locally by Beyers $e t$ al. (1968), as well as with those of Christensen (1969) for Thompson Seedless, where a decline was observed through the bloom period followed by a slight increase into midsummer.

The $K$ concentrations in both blades and petioles decreased steadily from the beginning of bloom up to harvest. These results are in close agreement with those reported by Beyers et al. (1968) and Christensen (1969).

The $\mathrm{Ca}$ concentration of both the blades and the petioles increased from bloom until harvest, the only relatively stable period being, as for $P$, the month following bloom. This is in accordance with the results of Beyers et al. (1968), Christensen (1969) and Cummings (1977).

The $M g$ concentration of the petioles increased slowly at the beginning of the season, and was followed by sharp increases during the remainder of the season-an observation reported previously (Cummings, 1977). The $\mathrm{Mg}$ concentration in the blades showed a small but consistent increase during the season. This is in contrast to the results of Cummings (1977). However, Beyers et al. (1968) also reported an increase in $M g$ concentration.

Considering the seasonal variations in leaf concentrations of $N, P, K, C a$ and $M g$ it appears that the most suitable tissue to analyse is the petiole, and the most stable time for sampling is during the month following bloom. This is in accordance with conclusions reached by 

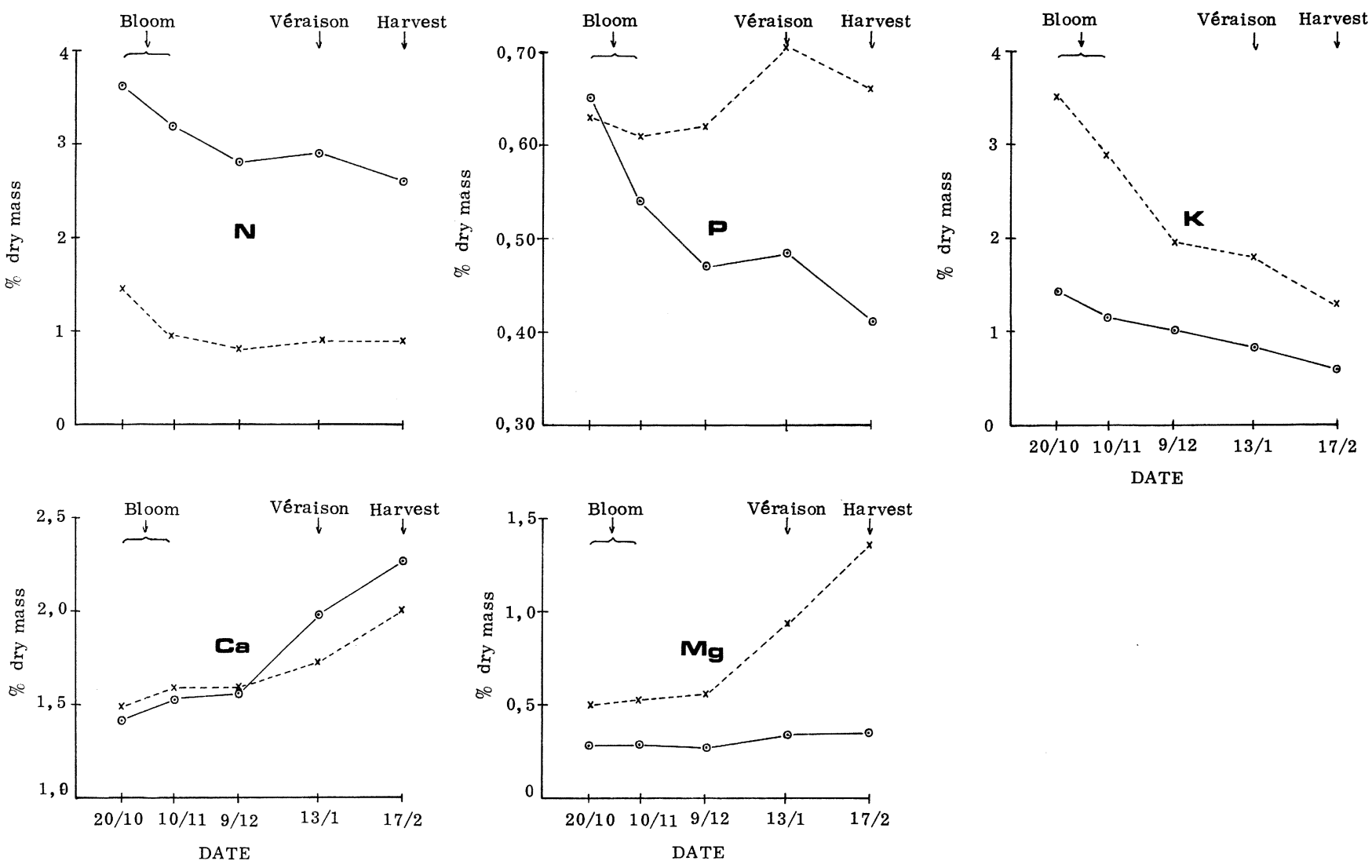

FIG. 1

Seasonal changes of $N_{-}, P-, K-, C a-$ and $M g-$ levels in leaf

blades and petioles from Chenin blanc/99R grown in sand culture. Blades $\odot-\odot$; Petioles $\mathbf{x}----\mathbf{x}$.

other workers (Christensen, 1969; Alexander \& Woodham, 1970). However, figures obtained for $K$ at this stage, or any other period, may give variable results. Furthermore, this period (one month after bloom) coincides with the stage when nutrients (with the exception of $K$ ) in the petiole are at or near the lowest level for the season. More research is needed in order to determine whether analytical results from petioles sampled at this stage can be used to determine whether or not vineyards are adequately nourished (Christensen, 1969).

The seasonal pattern for leaf blades generally corresponded well with that found locally by Beyers et al. (1968). However, because Chenin blanc is an earlier ripening variety than either Waltham Cross or Barlinka, the correction curves drawn by the above authors do not hold good for Chenin blanc.
The total nutrient contents of the vine leaves in $\mathrm{mg} /$ vine are shown in Table 2 . The $N$ and $P$ content of the blades increased steadily up to véraison, decreasing thereafter until after harvest, and finally increased again during the period of leaf fall. The same pattern was exhibited by the petioles, except that losses occurred during the period of active leaf fall. For $K$ translocation started before véraison and was of a larger magnitudeprobably due to the high mobility of $K$, and the loss was fully recovered during the five weeks immediately following harvest. In contrast to $N$ and $P$ there were further translocations of $K$ from the blades during leaf fall. Both the blades and the petioles showed gains for $C a$ and $M g$ throughout the season-the only exception being a small decrease in the $\mathrm{Ca}$ content of the petioles just after harvest.

TABLE 2

Seasonal changes in $N, P, K, C a$ and $M g$ contents (mg/vine) of leaves from Chenin blanc/99R vines grown in sand culture

\begin{tabular}{|c|c|c|c|c|c|c|c|c|c|c|c|}
\hline \multirow{2}{*}{$\begin{array}{l}\text { Sampling } \\
\text { Date }\end{array}$} & \multirow{2}{*}{ Growth Stage } & \multicolumn{2}{|c|}{$N$} & \multicolumn{2}{|c|}{$P$} & \multicolumn{2}{|c|}{$K$} & \multicolumn{2}{|c|}{$\mathrm{Ca}$} & \multicolumn{2}{|c|}{$M g$} \\
\hline & & Blades & Petioles & Blades & Petioles & Blades & Petioles & Blades & Petioles & Blades & Petioles \\
\hline $\begin{array}{l}10 / 20 \ldots \ldots \\
11 / 10 \ldots \ldots \\
12 / 9 \ldots \ldots \\
1 / 13 \ldots \ldots \\
2 / 17 \ldots \ldots \\
3 / 22 \ldots \ldots \\
5 / 5 \ldots \ldots \\
6 / 23 \ldots \ldots\end{array}$ & 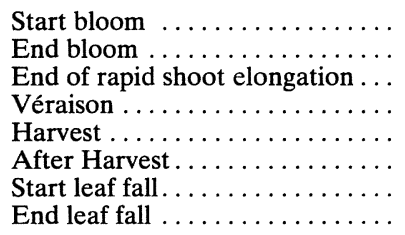 & $\begin{array}{ll}1 & 286 \\
2 & 184 \\
2 & 829 \\
3 & 304 \\
2 & 818 \\
2 & 449 \\
2 & 457 \\
3 & 066^{1}\end{array}$ & $\begin{array}{r}59 \\
75 \\
88 \\
114 \\
111 \\
97 \\
108 \\
74^{1}\end{array}$ & $\begin{array}{l}228 \\
365 \\
470 \\
544 \\
433 \\
399 \\
540 \\
683^{1}\end{array}$ & $\begin{array}{l}22 \\
47 \\
69 \\
91 \\
81 \\
63 \\
64 \\
62^{1}\end{array}$ & $\begin{array}{r}531 \\
783 \\
1059 \\
977 \\
683 \\
1054 \\
1089 \\
1036^{1}\end{array}$ & $\begin{array}{l}124 \\
225 \\
219 \\
233 \\
146 \\
222 \\
237 \\
187^{1}\end{array}$ & $\begin{array}{ll}502 \\
1 & 031 \\
1 & 575 \\
2 & 239 \\
2 & 437 \\
2 & 396 \\
2 & 770 \\
3 & 427^{1}\end{array}$ & $\begin{array}{r}52 \\
122 \\
174 \\
221 \\
243 \\
208 \\
209 \\
223^{1}\end{array}$ & $\begin{array}{c}98 \\
189 \\
271 \\
380 \\
392 \\
419 \\
528 \\
637^{1}\end{array}$ & $\begin{array}{r}17 \\
42 \\
64 \\
118 \\
165 \\
168 \\
190 \\
208^{1}\end{array}$ \\
\hline
\end{tabular}

${ }^{1}$ Shed leaves collected during leaf fall. 
As suggested by Beyers (1951), seasonal variations in the nutritional contents of leaf blades positioned at the middle of a shoot may be decreased by expressing the nutritional contents on an absolute basis i.e. $\mathrm{mg}$ of nutrient contained per leaf. In this experiment all the leaves on a vine were used and when expressed as $\mathrm{mg}$ of nutrient per leaf (not shown) the figures obtained from Table 2, therefore, compare with the actual values for middle leaves. However, the nutrient concentration in the petioles still appears to give a better indication of the actual nutritional status.

\section{SUMMARY AND CONCLUSIONS}

The amounts of $N, P$ and $K$ consumed by the crop and vegetative growth, as determined in this experiment, compare well with results obtained elsewhere, whereas the differences observed for $C a$ and $M g$ may probably be ascribed to the nature of the soil on which the field experiments of other researchers were conducted.

The permanent structure of the vine showed a relatively large seasonal demand for additional nitrogen $(0,73$ $\mathrm{kg}$ /ton of grapes). This was due to increased root growth and enlargement of the permanent structure, and should be taken into account when applying a fertilizer programme. Assuming that all the leaves and prunings are returned to the soil, the seasonal demand for $N, P, K, C a$ and $M g$ amounts to 2,$12 ; 0,35 ; 2,17 ; 0,31$ and $0,17 \mathrm{~kg} /$ ton of grapes produced, which is regarded as realistic for local conditions.

In accordance with results obtained in other countries, leaf petioles sampled about one month after bloom generally appeared to be the most stable tissue when analysed for $N, P, C a$ or $M g$. For $K$ no such stable period was noticeable. In this experiment, using adequately nourished vines, the nutrient concentrations in the petioles analysed at this stage amounted to 0,$96 ; 0,61$; 2,90; 1,59 and $0,54 \%$ for $N, P, K, C a$ and $M g$, respectively.

Apart from the figure for $P$, which appears to be rather high, the other figures compare reasonably well with results obtained by other researchers in field trials.

The consumption figures as determined in this experiment may, therefore, be used in order to plan and apply a realistic fertilization programme under climatic conditions found in South Africa. Although reliable norms should be established for petiole analyses, results from such analyses can be used as guidelines.

\section{LITERATURE CITED}

ALEXANDER, D. McE. \& WOODHAM, R. C., 1970. Chemical composition of leaf tissues of Sultana vines grown in nutrient solutions deficient in macro-elements. Vitis 9, 207 $-217$.

BEYERS, E., 1951. Leaf analysis in relation to plant nutrition. Farm. in S. Afr. 26, 173-176.

BEYERS, E., 1962. Diagnostic leaf analysis for deciduous fruit. S. Afr. J. agric. Sci. 5, 315-329.

BEYERS, E., PIENAAR, W. J. \& TERBLANCHE, J. H., 1968. Seasonal trends in leaf composition of deciduous fruit. Decid. Fruit Grow. 18, 87-92.

CHRISTENSEN, P., 1969. Seasonal changes and distribution of nutritional elements in Thompson Seedless grapevines. Am. J. Enol. Vitic. 20, 176-190.

CONRADIE, W. J., 1980. Seasonal uptake of nutrients by Chenin blanc in sand culture. I. Nitrogen. S. Afr. J. Enol. Vitic. 1, 59-65.

CONRADIE, W. J., 1981. Seasonal uptake of nutrients by Chenin blanc in sand culture. II. Phosphorus, potassium, calcium and magnesium. S. Afr. J. Enol. Vitic. 2, 7-13.

COOK, J. A., 1966. Grape Nutrition. In: Childers, N.F. (Ed.): Fruit Nutrition 777-812. Horticultural Publications, New Jersey.

CUMMINGS, G. A., 1977. Variation in the concentration of certain elements in Muscadine grape leaves related to season, leaf portion, and age. J. Am. Soc. Hort. Sci. 102, 339-342.

DELAS, J., 1968. A study by foliar analyses of magnesium deficiency in vines of the Bordeaux region. Mem. gen. II Coloq. eur. medit. Contr. Fert. Plant. cult., Seville, 343 -350 (Abstr.: Hort. Abstr. 41, 6246, 1971).

EGGENBERGER, W., KOBLET, W., MISCHLER, M., SCHWARZENBACH, H. \& SIMON, J., 1975. Weinbau, Chapter 2, Verlag Huber \& Co., Frauenfeld.

LAFON, J., COUILLAUD, P., GAY-BELLILE, F. \& LÉVY, J. F., 1965. Rythme de l'absorption minérale de la vigne au cours d'un cycle végétatif. Vignes Vins 140, 17-21.

LÉVY, J. F., CHALER, G., CAMHAJI, E. \& HÉGO, C., 1972. Neue statistische Untersuchungen über die Zusammenhänge zwischen dem Mineralstoffgehalt der Blätter und den Ernährungsbedingungen der Rebe. Vignes Vins 212, 21-25.

MAROCKE, R., BALTHAZARD, J. \& CORREGE, G., 1976. Exportations en éléments fertilisants des principaux cépages cultivés en Alsace. C.R. Agric. 420-429.

WINKLER, A. J., COOK, J. A., KLIEWER, W. M. \& LIDER, L. A., 1974. General Viticulture, Chapter 17. University of California Press, Berkeley. 